\title{
TOTAL FACTOR PRODUCTIVITY OF MAJOR CROPS IN CENTRAL INDIA
}

\author{
Olayiwola O.O., Awasthi P.K., Raghuwanshi N.K., Researchers \\ Jawaharlal Nehru Krishi Vishwa Vidyalaya Agricultural University, Jabalpur, India \\ E-mail: olubodun 2008@yahoo.com
}

\begin{abstract}
S
The study estimated total factor productivity for principal crops in Madhya Pradesh using time series secondary data on area, production productivity of major crops in Madhya Pradesh. The Malmquist model is selected over Tornqvist model for the study because of stationality and redundancy problem associated with time series. Structural changes occurred in area and production of principal crops during the specific period of time due to policy effect and autonomous production as well. The variability in the total outputs and total inputs index was due to exploitation of available production potential in the state. Malmquist total factor productivity index explained the stages of production in Madhya Pradesh over periods of time. Post global and combine periods were better as compared with pre global period. Total factor productivity is a comprehensive measure of productivity and has gained acceptance among government officers, policy makers, productivity specialist and economist.
\end{abstract}

\section{KEY WORDS}

Productivity; Crops; Central India.

The state of Madhya Pradesh is also known as Central India and is the second largest state of the country in terms of its geographical spread. It is primarily an agriculture state and about 70 per cent population of the state is rural, which directly or indirectly depends on agriculture. Thus, agricultural sector is the mainstay of the state economy. The agriculture and allied services contribute about 23 per cent share in state economy and 65 per cent of its working force directly depend on agriculture [7]. Agriculture continues to be the major source of income for most of the population and therefore measurement of total factor productivity growth over time for the state of Madhya Pradesh is crucial importance, since agriculture sector supplies raw materials to manufacturing sector and also provide market for manufactured products.

There are two measures of productivity, partial factor productivity and total factor productivity. Partial factor productivity is the ratio of output to be a single input. Total factor Productivity (TFP) is a ratio of an index of aggregate output to aggregate input. TFP is one of the most convenient indicators to evaluate economic performance as an ex-post facto. Earlier approaches to productivity measurement were based upon partial productivity indices, typically land or labour productivity only due to computation simplicity or feasibility. There are many of the factors accounting for observed production growth. It is a misleading measure of grains in productive efficiency since it does not allow factor substitution over time. Since total factor productivity can account for productivity for the whole set of inputs used in the production process, it is superior to other productivity measures. TFP may also reflect technological improvement realized in an economy [14].

The source of TFP growth is not only technological progress but also progress in the quality of inputs or efficiency improvements depend on better organization or institutional restructuring. Growth rate of agricultural production simply depict performance of agriculture but does not reveal anything about efficiency of the performance. However, factor productivity reveals efficiency with which the factors inputs are converted into output within production processes [5].

Total factor productivity provides society opportunity to increase the welfare of people in the society. Therefore, accurate measurement of TFP is crucial to understand changes in productivity growth. The study was conducted at Madhya Pradesh and secondary data related to principal crops are used for the study. Madhya Pradesh is situated at the heart of India and lies between latitude $21^{\circ} 6$ and $26^{\circ} 54^{\prime} \mathrm{N}$ and longitude $74^{\circ}$ and $82^{\circ} 47^{\prime} \mathrm{E}$. It covers a geographical area of 308,245 sq.km which is about $9.38 \%$ of the total area of India [9]. Uttar 
Pradesh, Chhattisgarh, Andhra Pradesh, Maharashtra, Gujarat and Rajasthan are neighboring states to Madhya Pradesh. Narmada River is the oldest river present at Madhya Pradesh and is known as lifeline of Madhya Pradesh.

The study has become significant for both farmers and policy maker.

For Policy Maker:

- The study will serves as strategies frame work for decision making at state krishi Nitti

- It will also ensure efficient and a clear cut linkage supply system of inputs that will contribute huge quota to the TFP of the principal crops in the study area

- This study will enable the government to design clear and feasible programmes and policies that will be in line with agricultural sector needs in the state.

For farmers:

- The farmers can used the study as guidelines for allocation of scarce resources during production

- Farmers can also used the study to determine the optimization levels which give maximum return with least cost minimization

\section{WORKING HYPOTHESIS}

Total factor productivity for major crops is not declining in Madhya Pradesh.

\section{METHODOLOGY}

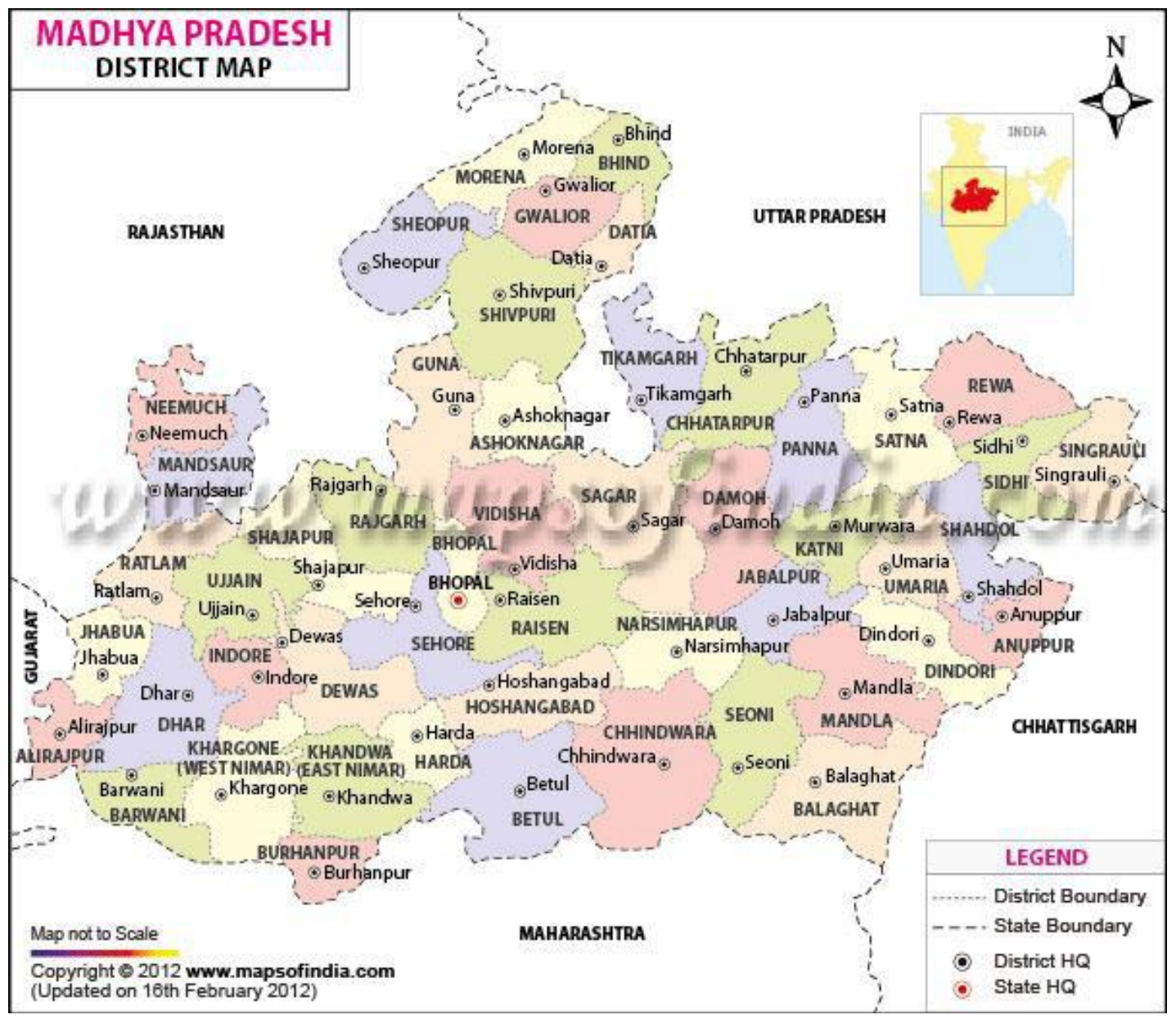

Source: Google map

The study was conducted at Madhya Pradesh. The state lies between latitude 2106' and 26054' $\mathrm{N}$ and longitude $74 \mathrm{o}$ and 82047' E. It covers a geographical area of 308, 245 sq. 
$\mathrm{km}$ which is about $9.38 \%$ of the total area of India. Secondary data from different sources of data bank were used for the study. The list of the data sources are:

(a) Area, Production and Yield of major crops in Madhya Pradesh published yearly by Directorate of Agriculture, Madhya Pradesh, Bhopal.

(b) Tables of Agricultural Statistics of Madhya Pradesh published yearly by Commissioner of land Records \& Settlement, Gwalior, Madhya Pradesh

(c) Compendium of Agricultural Statistics published yearly by Agricultural Department of Madhya Pradesh State agricultural Marketing Board, Bhopal.

(d) Cost of Cultivation Principal Crops in India published yearly by Ministry of Agriculture.

(e) Agricultural Statistics at a Glance published yearly by Agricultural Statistics Division, Directorate of Economics \& Statistics, Department of Agriculture and Co operations, GOI, New Delhi.

Analytical tools. The Malmquist model is selected over Tornqvist model for the study because of the following reasons:

I. It help to solve problem associated with redundancy

II. It provides information about inter-regional and temporal variation associated with time series data.

III. It also caters for stationality and non-stationality problems associated with time series data

IV. It assumed that the producers behave competitively

V. It shows the separation between input-output production technology

VI. It assumed both technical efficiency and inefficiency

The Malmquist TFP index was first introduced by [11]. Malmquist productivity index is given by

$$
\begin{aligned}
M^{t} & =\frac{D_{O}^{t}\left(\mathbf{x}^{t+1}, \mathbf{y}^{t+1}\right)}{D_{O}^{t}\left(\mathbf{x}^{t}, \mathbf{y}^{t}\right)} \\
M^{t+1} & =\frac{D_{O}^{t+1}\left(\mathbf{x}^{t+1}, \mathbf{y}^{t+1}\right)}{D_{O}^{t+1}\left(\mathbf{x}^{t}, \mathbf{y}^{t}\right)}
\end{aligned}
$$

Fare et al [15] define Malmquist productivity change index as the geometric mean between two-period indices and it is expressed as:

$$
\begin{gathered}
M_{O}\left(\mathbf{x}^{t+1}, \mathbf{y}^{t+1}, \mathbf{x}^{t}, \mathbf{y}^{t}\right)=\left[\left(\frac{D_{o}^{t}\left(\mathbf{x}^{t+1}, \mathbf{y}^{t+1}\right)}{D_{o}^{t}\left(\mathbf{x}^{t}, \mathbf{y}^{t}\right)}\right)\left(\frac{D_{o}^{t+1}\left(\mathbf{x}^{t+1}, \mathbf{y}^{t+1}\right)}{D_{o}^{t+1}\left(\mathbf{x}^{t}, \mathbf{y}^{t}\right)}\right)\right]^{\frac{1}{2}} \\
\operatorname{Mo}\left(\mathrm{x}^{t+1}, \mathrm{y}^{t+1}, \mathrm{x}^{t}, \mathrm{y}^{t}\right)=\frac{D_{o}^{t+1}\left(x^{t+1}, y^{t+1}\right)}{D_{o}^{t}\left(x^{t}, y^{t}\right)}\left[\left(\frac{D_{o}^{t}\left(x^{t+1}, y^{t+1}\right)}{D_{o}^{t+1}\left(x^{t+1}, y^{t+1}\right)}\right)\left(\frac{D_{o}^{t}\left(x^{t}, y^{t}\right)}{D_{o}^{t+1}\left(x^{t}, y^{t}\right)}\right)\right]^{\frac{1}{2}} \\
\text { Where Efficiency change }=\frac{D_{o}^{t+1}\left(x^{t+1}, y^{t+1}\right)}{D_{o}^{t}\left(x^{t}, y^{t}\right)} \\
\text { Technical change }=\left[\left(\frac{D_{o}^{t}\left(x^{t+1}, y^{t+1}\right)}{D_{o}^{t+1}\left(x^{t+1}, y^{t+1}\right)}\right)\left(\frac{D_{o}^{t}\left(x^{t}, y^{t}\right)}{D_{o}^{t+1}\left(x^{t}, y^{t}\right)}\right)\right]
\end{gathered}
$$




\section{RESULTS OF RESEARCH}

Growth rate in total output index, total input index and total factor productivity in the state of Madhya Pradesh is given in table1. The estimates of the growth rate of indices shows that during the study period (1990-91 to 2011-12), the growth in total output was higher than the growth in total input index and therefore there was positive growth in total factor productivity (TFP).

The same higher total output was reported in all the selected principal crops in Madhya Pradesh but wheat crops has the highest total output, followed by soybean, lentil, gram, mustard, cotton and paddy crops. The input indexes are the same in cotton, mustard and grams crops and lentil crops has the highest value of total inputs index, followed by soya bean, paddy and wheat crops with the lowest value. The variability in the total outputs and total inputs index among the selected principal crops in Madhya Pradesh might be due to exploitation of available production potential in the state through use of appropriate inputs and production technology. The findings are in line with some scholar works such as $[5,9,14]$.

Table 1 - Growth Rate in Output and Inputs Indices (1990-91 to 2011-12)

\begin{tabular}{|c|c|c|c|c|}
\hline S. No. & Crops & Total Output Index & Total Inputs Index & Total Factor Productivity \\
\hline 1 & Paddy & 0.71 & 0.62 & 0.09 \\
\hline 2 & Wheat & 0.96 & 0.60 & 0.36 \\
\hline 3 & Gram & 0.84 & 0.61 & 0.23 \\
\hline 4 & Lentil & 0.86 & 0.69 & 0.17 \\
\hline 5 & Soy bean & 0.90 & 0.63 & 0.30 \\
\hline 6 & Mustard & 0.83 & 0.61 & 0.22 \\
\hline 7 & Cotton & 0.81 & 0.61 & 0.20 \\
\hline
\end{tabular}

The trend in total output index, total input index and total factor productivity indices in Madhya Pradesh in the crop sector (aggregate of seven crops as a whole are presented in table 2. The data revealed that during pre- global period the total output index was higher than the total input index resulting in total factor productivity more than 100.

Table 2 - Total Factor Productivity Index of selected crop in central india based on malmquist index

\begin{tabular}{|c|c|c|c|c|}
\hline Periods & $\begin{array}{c}\text { Total } \\
\text { Output } \\
\text { Index }\end{array}$ & $\begin{array}{c}\text { Total } \\
\text { Input } \\
\text { Index }\end{array}$ & $\begin{array}{c}\text { Total Factor } \\
\text { Productivity }\end{array}$ & Sequential Malmquist TFP Index \\
\hline $\begin{array}{c}\text { Pre-Global } \\
(1990-91 \text { to } \\
2000-01)\end{array}$ & 107 & 103 & 105 & $\begin{array}{c}(0.51-0.76) \text { Small level at Decreasing Return } \\
(<1) \text {.TFP in M.P still at stage 1 with technical } \\
\text { regress. Incremental Inputs yield less of } \\
\text { incremental output }\end{array}$ \\
\hline $\begin{array}{c}\text { Post- Global } \\
(2002-02 \text { to } \\
2011-12)\end{array}$ & 116 & 111 & 115 & $\begin{array}{c}(1.44-1.82) \text { Marginal level at Increasing Return }(>1) . \\
\text { Stage 1 with technical progress result to increase in } \\
\text { efficiency \& TFP in M.P }\end{array}$ \\
\hline $\begin{array}{c}\text { Combine (1990- } \\
91 \text { to 2011-12) }\end{array}$ & 114 & 110 & 104 & $\begin{array}{c}(1.25-1.67) \text { Marginal level at Increasing Return }(>1) . \\
\text { TFP is at stage 1 with technical progress in Madhya } \\
\text { Pradesh }\end{array}$ \\
\hline
\end{tabular}

During post- global period and combine period the similar trend was observed but total factor productivity was higher during post-global period for crop sector as a whole. The increasing total factor productivity in the state may be due to the increasing gross capital formation in the Madhya Pradesh during the post-global period. This is thus liable to reject the hypothesis of declining total factor productivity over period in the state.

The sequential malmquist total factor productivity index explained the stages of production in Madhya Pradesh over periods of time that were re-arranged as pre-global (1990-91 to 2000-01), post- global(2002-02 to 2012-13) and combine (1990-91 to 201112).During pre-global, there was technological backward in the study area and efficiency ranges between (0.51-0.76) and farmers operate at small scale level with decreasing return and Total Factor Productivity in Madhya Pradesh is still at stage 1 with technical regress. 
The results of sequential malmquist total factor productivity were the same at post global and combine periods respectively. The efficiency at post global and combine periods were (1.44 to 1.82) and (1.25 to 1.67) respectively. Farmers in Madhya Pradesh operate at marginal level resulted to increasing return and the technical progress was observed. The total factor productivity was at stage 1 and efficiency increased during both post-global and combines periods. The result is similar to [5] finding.

Table 3 - Sources of Growth in Total Factor Productivity in central india

\begin{tabular}{|l|c|c|c|}
\hline \multicolumn{1}{|c|}{ Particulars } & $\begin{array}{c}\text { Pre-Global (1990-91 to } \\
2000-01)\end{array}$ & $\begin{array}{c}\text { Post- Global (2002-02 } \\
\text { to 2011-12) }\end{array}$ & $\begin{array}{c}\text { Combine (1990-91 to } \\
2011-12)\end{array}$ \\
\hline Fertilizer & 0.14 & 0.10 & 0.09 \\
\hline Manure & 0.26 & 0.15 & 0.11 \\
\hline Human labour & 0.16 & 0.11 & 0.14 \\
\hline Animal labour & 0.04 & 0.09 & 0.07 \\
\hline Rent Value & 0.06 & 0.14 & 0.22 \\
\hline Seed & 0.34 & 0.41 & 0.37 \\
\hline Total Factor Productivity Growth & 1.00 & 1.00 & 1.00 \\
\hline
\end{tabular}

The source of total factor productivity growth was analyzed. Partial contribution of input and total factor productivity growth was estimated in table 3. Data inferred that among the inputs considered for the study, the contribution of rent value and human labour was higher during combine period but seeds contribution was also higher throughout the three stages (combine, pre and post global periods). Manure contribution was also notable and high during pre-global despite low values during post-global and combine periods. The result is similar to $[7,13]$ findings.

\section{CONCLUSION}

Total factor productivity of agriculture in Madhya Pradesh is still having great potential since it is not declining and it shows positive growth. Total factor productivity (TFP) growth is not declining as it is observed in the states like Punjab and Haryana. The reason for the great potential in TFP in Madhya Pradesh was as a result of proper allocation of resources in right direction. The following major recommendation emerged from the study and they are:

- There is a need for government to subsidies price of seeds and to encourage more hybrid seeds that will enhanced more outputs.

- Adequate farm inputs must be made available to the farmers and government must follow a clear channel supply systems of inputs..

- Strengthening support and Public-Private Partnership so as to boost production and win niche markets with a challenge of making better markets for farmers, while at the same time ensuring that production technologies adopted is more environmentally sustainable.

- Cost of Cultivation and yield risk factors will need to be taken care of by appropriate measures of principal crops in Madhya Pradesh of India.

- Non-price factors such as temperature, rainfall, humidity may be considered for future.

- There is a need for clear cut market supply for fertilizer distribution in Madhya Pradesh of India.

- There are needs for government to subsidies price of seeds and to encourage more hybrid seeds that enhanced more outputs.

- Adequate farm inputs must be made available at cheap price to the farmers and government must follow a clear channel supply systems of inputs.

- Frequency of extension visits should be increased to encourage wider spread and adoption of improved farm technology. 


\section{ACKNOWLEDGEMENTS}

This project is sponsored by African Union Commission funds for Advance Graduate Students in India.

\section{REFERENCES}

1. Ahaudhary M.S., Liyas M.2008. Trends in Total factor productivity in Pakistan agricultural sector. Pakistan Economic and Social review. 117-132.

2. Ahn Schmidt, P.,1995. Efficient Estimation of Models for Dynamic Panel Data. Journal of Econometrics. 68, 1, 5-28.

3. Anderson T.W.,Hsiao C.,1981. Estimation of Dynamic Models with Error Components. Journal of the American Statistical Association, 76, 598-606.

4. Arellano M., Stephen B.,1991. Some Tests of Specification for Panel Data.[ Monte Carlo Evidence and an Application to Employment Equations]. The Review of Economic Studies. 58, 277-97.

5. Bhattacharya B. B.,Sakthivel S.,2004. Regional Growth and Disparity in IndiaComparison of Pre- and Post-Reform Decades. Economic and Political Weekly. 6, 10711077.

6. Belloumi M., Mohammed S.,2009. Measuring agricultural productivity growth in NEMA Countries. Journal of Development and Agricultural Economics. 1,103-113.

7. Bhushan S., 2005.Total Factor Productivity Growth of Wheat in India. [A Malmquist Approach]. Indian Journal of Agricultural Economics. 60, 1-3.

8. Bosworth B., Collins S. M.,2007. Accounting for Growth. [Comparing China and India]. Working Paper 12943. National Bureau of Economic Research.

9. Bhalla G. S.,Singh G.,1996.Impact of GATT on Punjab Agriculture institute for Development and Communication. Monograph Series II.

10. Brauw A.,Huang G.,Roselle S.,2003.Sequencing and the Success of Gradualism. [Empirical Evidence from China's Agricultural Reform]. Presented at JUNU-IFPRI workshop on The Dragon and the Elephant. A Comparative Study of Economic and Agricultural Reforms in China and India.

11. Caves D.W., Christensen L.R., Diewert W.E., 1982.The economic theory of index numbers and the measurement of input, output and productivity.[Econometrical]. 50, 1393-1414.

12. Carlow K., Mawson P.,McClellan N.,2003. Productivity measurement. Alternative approaches and estimation. New Zealand Treasury paper. 3.

13. Coelli T. J., Rao D.S., Prasada.,2003. Total Factor Productivity Growth in Agriculture. A Malmquist Index Analysis of 93 Countries1980-2000. Centre for Efficiency and Productivity Analysis.[Working Paper Series 2]. University of Queensland Australia.

14. Epstein L., 2012.Duality Theory and Functional Forms for Dynamic Factor Demands. Review of Economic Studies. 48, 81-95.

15. Farrell L. E., Perrin R.K., 1994.Prices and Productivity in Agriculture. Review of Economics and Statistics.75, 471-482. 